\title{
ACCOUNTING MEASUREMENT MATRICES: SUBJECT AND VALUES
}

\author{
Elena Abdalova \\ Saint Petersburg State University of Economics, Russia \\ Svetlana Karelskaia \\ Saint Petersburg State University, Russia
}

\begin{abstract}
The paper is methodologically based on measurement matrices by E.O. Edwards - F.V. Bell and Y. V. Sokolov - V. Y. Sokolov. The authors carry out a comparative analysis of timefactor measurement matrices of American and Russian researchers. The analysis shows that the major difference lays in use of different objects of measurement that leads to variations in their interpretation and application. The conclusion that the concept of the mixed measurement applied in accounting, is a consequence of influence of time on a measurement of objects of the account is drawn.
\end{abstract}

Keywords: assets, converted value, fair value, measurement, time

JEL code: M400. M410

\section{Introduction}

In fact, Accounting is unthinkable without a roundup monetary measurement tool for estimation of heterogeneous accounting objects. This principle was one of the major prerequisites for emergence of double-entry accounting, i.e. an accounting system based on a double entry method and balance sheet. Its introduction into real-life practice allowed creating an accounting information model integrating all constituent elements of operational and financial activities of a company (Kuter, 2013, pp. 24-25). In this respect search for the optimal measurement types and methods of their application to accounting entities in order to achieve 'resourcefulness' of accounting data appears to become one of the most important objectives of the present-day accounting theory and practice worldwide.

Unfortunately, what appears to be helpful for one user is scarcely ever good for all others. The choice of measurement for accounting entities is pre-dominated by the interests of certain groups. This fact pre-conditioned two basic approaches to this issue:

1) application of a unified measurement to accounting entities - historical approach (A. C. Littleton, J. Ijiri, and others), or market-oriented approach (W.A. Paton, H. Sweeney, and others);

2) application of multiple measurement (Sokolov, 1991, pp. 162-163). J.B. Canning (1884 1962) was among the most famous supporters of the latter approach. He developed a three measurement model: historical measurement based on actual spending; historical measurement based on expected income from entities, and the current market measurement) (Sokolov, 1991, pp. 164-165). This approach was not duly appreciated and used in practice, however, the multiple measurement approach based on the asset-tailored measurement rule is widely recognized and practiced.

The objective of this publication is to specify the list and characteristics of types of measurement used in accounting practice within the concept of multiple measurement.

The research tasks are:

1) to conduct a comparative analysis of the results of researches focused on types of measurement of accounting entities changing with time. Among other researchers are such 
Americans E.O. Edwards and F.W. Bell, Y. V. Sokolov and Russians V. Y. Sokolov. They all used a special research method of building up time-based measurement matrices;

2) to reveal differences in matrices' structure and the obtained results;

3) to determine the new opportunities of this research method in order to specify the characteristics of certain types of asset measurement.

The paper is methodologically based on works on the evolution of research of the theory of accounting entities measurement: Whittington, G. (2015) 'Measurement in Financial Reporting: Half a Century of Research and Practice'. A special attention is paid to creation of classifications of the measurement types. A classification allows to work out ways to perceive a research object and, consequently, to facilitate further development of measuring methods.

The subject of the given article involves works by E. O. Edwards and F. W. Bell, Y. V. Sokolov and V. Y. Sokolov.

The comparative analysis of measurement classifications described via time-criterion matrices by American and Russian scientists resulted in revelation of their differences, directions of their further development in terms of specification of their application area and characteristics of certain types of measurement.

\section{Asset Valuation Matrix by Edgar O. Edwards and Philip Wilkes Bell}

In 1961 American researchers Edgar O. Edwards (1919-2010) and Philip Wilkes Bell ${ }^{1}$ (1924-2007) published their book 'The Theory and Measurement of Business Income'. This is a renowned book among experts in accounting measurement, as the described approach was used by James A. Ohlsen in 1995 when he developed his method of a firm valuation. Nowadays it is widely known as Edwards-Bell-Ohlson model (Ivanov, 2014, p. 37). The significant contribution by Edgar Edwards and Philipp Bell in the development of accounting theory and practice (in particular, their research 'The theory and measurement of business income') was highly estimated. In 2003 their names were listed in the Accounting Hall of Fame at Ohio State University, one of the most prestigious schools in the world of accounting.

The importance of contribution made by E.O. Edwards and P.B. Bell for the development of accounting theory is acknowledged by all researchers of the history of accounting and the measurement theory. Published in 1961, their work remains relevant nowadays. Its relevance is well demonstrated via Web of Science citation data which has fixed 322 references, including 50 from 2012 to 2016. The work was mentioned in publications on the history of accounting (Edwards, 2016; Whittington, 2015; Dyckman, Zeff, 2015, etc.) and business measurement (Gregory, Whittaker,2013; Koh, Qian, Wang, 2014, etc.).

The Edwards-Bell book has not yet been translated into Russian. Russian researchers know it from D. Alexander, A. Jorissen, and A. Britton's 'International Financial Reporting and Analysis' published in Russia in 2005. The authors gave a detailed description of EdwardsBell's accounting entities measurement matrix. Basically the model implies cross-reference of the influence of three parameters on the accounting asset value (Alexander D., 2005, p. 7677; Edwards, Bell, 1995, p. 77):

- $\quad$ The form (and place) of the asset to be measured: the present, initial and ultimate;

- $\quad$ The date of the cost applied for the value: the cost in the past, current and future;

\footnotetext{
${ }^{1}$ Edwards and Bell met at Princeton University in 1950. A year earlier Bell graduated it and became a professor of accounting. Edwards was older, and already a lecturer with practical experience in company management accounting. In 1951 he received his PhD degree in amortization measurement (Peasnell, Whittington, 2010, p. 516).
} 
- The market of the cost formation: the market for assets entry and the market for assets exit (Table1).

Table 1. An array of value concepts of Edwards and Bell

\begin{tabular}{|l|l|l|l|}
\hline $\begin{array}{r}\text { Form and } \\
\text { place } \\
\text { of asset } \\
\text { market }\end{array}$ & \multicolumn{1}{|c|}{ Initial inputs } & \multicolumn{1}{|c|}{ Present form } & \multicolumn{1}{|r|}{ Ultimate form } \\
\hline Past, entry & historic costs & discarded alternatives & irrelevant \\
\hline Past, exit & discarded alternatives & discarded alternatives & irrelevant \\
\hline Current, entry & current costs & present costs & irrelevant \\
\hline Current, exit & irrelevant & opportunity costs & current values \\
\hline Future, entry & $\begin{array}{l}\text { possible replacement } \\
\text { costs }\end{array}$ & $\begin{array}{l}\text { possible replacement } \\
\text { costs }\end{array}$ & irrelevant \\
\hline Future, exit & irrelevant & possible selling values & expected values \\
\hline
\end{tabular}

(Table: Edwards, Bell, 1995, p. 77)

By employing the parameters mentioned above, they obtained 18 possible alternative versions for assets measurement and divided them into three groups: measurements instrumental for management decision-making (6); irrelevant measurements (6) and those dismissed (3) and left unattended (3).

Measurements instrumental for management decision-making involved: sale costs measurement - best opportunity costs, current values, expected values; and measurement for purchase: historical costs, current costs, present costs. Y. V. Sokolov (1938-2010) and V. Y. Sokolov claimed the Edwards and Bell's description of expected values their most important contribution into the theory of accounting (V. Y. Sokolov, 2006, p. 59; Y. V. Sokolov, 2010, pp.116-117). This type of measurement is used in business practice, in insurance agreements, in accounting of deferred taxes and payments on shares.

G. Whittington, a researcher of the accounting measurement theory evolution defined their two provisions as the most important contribution into accounting theory: 1) a proposition to apply two kinds of market measurement: 'entry value' and 'exit value', and 2) development of the economic analysis system based on the concept of residual income (Whittington, 2015, pp. 551-552).

\section{Y. Sokolov and Y. V. Sokolov's measurement model of business events}

The Edwards-Bell research was continued by Russian scientists. V. Y. Sokolov was the first to touch upon the issue of time influence in accounting measurement. His article 'Measurements: their types and meaning' was published in 1996 and later was followed by a book 'Theoretical basis of double accounting' (2006) and chapters in a joint research work 'Fundamentals of the theory of accounting' (2000) and in 'Bookkeeping as a total of events in doing business' (2010) with Y. Sokolov.

Y. V. Sokolov and V. Y. Sokolov used the measurement matrix based on only two parameters, i.e. time for measurement definition (the past, present and future) and time of a business event (V. Y. Sokolov, 2006, p. 54; Y. V. Sokolov, 2010, pp. 92-93). Russian researchers did not consider the market influence on the accounting asset measurement and replaced this Edwards - Bell analysis with that of time of a business event performance. The model they obtained presents three homogeneous types of measurement: cost-based, i.e. measurement of the past events, income-based, i.e. measurement of the future events, and market-based, i.e. measurement of the current events (V. Y. Sokolov, 2006, p. 59-60). Therefore, despite ignoring the market factor from the measurement analysis, it still remained, 
as cost-based measurement is in fact the purchase price, and the income-based measurement is the selling price. Market measurements involve transitional value. Measurement of the replacement asset value is that of the purchase price, the liquidation cost measurement is that of the selling price, whereas the fair value has no exact definition as to what market it refers. The fair value makes the core of the model (system) of measurement. The indefinite character of its content is connected with the chosen measurement asset, or a business event.

The authors of the present article believe that the role of the fair value in the 'time-based' matrix shall depend on the approach used for its formation. IFRS 13 describes three approaches: cost-based, market-based and income-based. Standards of measurement practice and financial reporting describe methods, algorithm, and hierarchal structuring of fair value. The existing approaches are united by the fact that as a result of their application we obtain the identically named value - the fair value. However, in each approach the value definition basis is different. This results in the fair value migration between the present and past and future across the 'time' model. The market-based approach of a fair value definition shall correspond to the time of an event measurement in the present and the current time economic conditions of measuring. The fair value measured on the basis of cost-based approach shall occupy the place of the present in the past of the model, whereas the implementation of income-based approach sets the place for the fair value as the present in the future.

The revealed differences show the ambiguousness in the interpretation of the above mentioned types of accounting assets measurement. An important result of Y. V. Sokolov and V. Y. Sokolov research is specification of the content and area of application of the two types of measurement acknowledged by American scholars: not instrumental for management decision-making (residual value) and dismissed and set aside (comparable measurement).

Summing up the results of their research, Sokolov emphasized three criteria of 'time' analysis relevance for accounting measurement, i.e. correct comprehension of measurement (formal qualification), effective application of existing measurements, and construction of new measurements (V. Y. Sokolov, 2006, p. 60, Y. V. Sokolov, 2010, p. 119).

Study of measurement models and matrices, classification criteria of accounting assets and the content of classification groups are inherent for the further development of the accounting theory and practice.

\section{Converted value}

Among examples of further development of accounting methods based on research and application of measurement matrices is a new type of measurement - 'converted value' offered by one of the authors of the given article. Converted value serves to specify the measurement of fixed capital assets which were updated, reconstructed, additionally equipped, or partially liquidated (Abdalova, 2012, pp. 26-34).

A fixed asset is taken into accounting with its initial cost. In the course of the useful life of assets its original value can modify: first of all, as a result of valuation adjustment, secondly, because of reconstruction, updating, additional construction and/or equipment, technical upgrading and/or partial liquidation of the asset.

The practice of valuation adjustment of fixed capital assets allows to fix in the accounting the change in the sum of expected economic benefits from the asset further use. This change is not connected with purposeful physical alteration of the fixed capital asset and is rather a result of the change of exogenous factors in relation to the revaluated asset and its owner. In essence, this practice is a consequence of time influence on the measurement of fixed capital 
assets and results in the formation of a new type of measurement called replacement asset value or converted value.

Updating, reconstruction, additional equipment or partial liquidation of fixed capital assets modify accounting assets as a result of which their performance specifications and expected financial gain also change. Historical cost of a fixed capital asset changes by the sum of the costs built up at different periods of time and in different life cycles of the fixed capital assets (starting from the time they were bought or somehow created to their reconstruction, updating, additional equipment or finishing construction and partial liquidation). In practice we have to face the fact that as a result of reconstruction, updating, additional equipment or finishing construction and partial liquidation there appears a new value which in its essence is neither its historical cost, nor replacement asset value. It is this type that the author suggests calling 'converted value'. Converted value is a specific type of fixed capital assets measurement applied to entities which have undergone reconstruction, updating, additional equipment or finishing construction and/or their partial liquidation. Converted value of fixed capital assets includes their historical costs (or replacement (revalued) asset value depending on the measurement model of fixed capital assets used in the company) and further costs of reconstruction, updating, additional equipment, and/or partial liquidation of the assets.

Therefore, implementation of a new measuring model in accounting will make it possible to achieve compliance between the causes of change in the historical costs of fixed capital assets and types of measurement which would qualify the sum of the future financial gains expected from the asset's further use. The change in valuation of fixed capital assets results in modeling replacement asset value.

Reconstruction, updating, additional construction and/or equipment, and/or partial liquidation of fixed capital assets build up another type of measuring, i.e. converted value.

\section{Conclusions}

Having summed up the results of the comparative analysis of two approaches to the research of the influence of time on accounting measurement, the authors came to the following conclusions:

1) The analysis displayed that time-based measurement matrices by E.O. Edwards - P.W. Bell and by Y. V. Sokolov - V. Y. Sokolov have a whole range of specific differences both in their construction parameters and in the relation towards the obtained results. E. O. Edwards and P.W. Bell used nine parameters in their model by matching three forms of the assets location and three dates for measuring formed on the purchase markets, and also three dates for measuring formed on the sales market. Y. V. Sokolov and V. Y. Sokolov applied six parameters for measurement modeling with three periods of time for the measured asset in three measurements related to the time of their valuation. Application of various quantity of modeling parameters technically resulted in a different number of measurement types.

2) It has been revealed that fair value has a migrating character within the time matrix depending on the approach chosen for defining its cost value which varies from the present in the past to the present in the future.

3) It has been specified that model construction of discounting rates is an effective research tool which allows to reveal new measurements and specify the existing ones.

4) The paper performed that the asset used by E. O. Edwards and P. B. Bell as a measurement entity transforming in time in the process of production, did not allow scholars to reveal the area of application of two kinds of measurement (that of the remaining value and comparable measurement) which were later on proposed by Y. V. Sokolov and V. Y. Sokolov. 
5) It has been proposed to introduce a new kind of measurement, i.e. of 'converted value' to provide characteristics for fixed assets the value of which was changed as a result of their reconstruction, modernization, construction extension, further equipment and/or partial liquidation.

6) The authors find it reasonable and viable to propose setting up a new accounting field, i.e. 'measurement studies'. This new discipline shall be based on summarizing of the existing theoretical and practical experience of accounting measurement application which might serve a future incidence for the development of accounting theory and practice. The new discipline might be structured as follows: definition of concepts (nomenclature and terms), correlation of accounting principles and the concepts of measurement, correlation of capital maintenance concepts and the models of discount rates; measurement kinds and classifications; time models of measurement; model; building for new kinds of measurement; building up information (cost/value) measurement pyramids, etc.

The obtained research data can be applied in further research of methods of accounting assets measurement, in financial analysis and in measurement and valuation. This appears important, as the obvious trend for expansion of accounting methods (types) of measurement is conditioned by the need in multi-variant ways of information performance for the purposes of decision-making. The major field of the paper results application likewise of all studies dedicated to time analysis in accounting measurement founded by Fabio Besta (1845-1923) and L. Gomberg (1866-1935) (V.Y. Sokolov, 2006, p. 60), can become designing of new types of measurement and more efficient use of the existing ones.

\section{Literature}

Abdalova E. B. (2014). The historical aspect of the category accounting estimate. Theory and practice of service: The economy, social sphere, technology, no. 3 (13), pp.255-261 (Абдалова Е. Б. Исторический аспект развития категории учетной оценки // Теория и практика сервиса: экономика, социальная сфера, технологии. 2012. № 3 (13), с. 255261). (in Russian)

Alexander D., Britton A., Jorissen E. (2005). International Accounting Standards: from theory to practice - Moscow: Vershina. (Александер Д., Бриттон А., Йориссен Э. Международные стандарты финансовой отчетности: от теории к практике/ пер. с англ. - М.: Вершина, 2005). (in Russian)

Dyckman T. R., Zeff S. A. (2015), Accounting Research: Past, Present, and Future, Abacus, Vol. 51, No. 4, pp. 511-524.

Edwards E. O., Bell P. W. (1995). The theory and measurement of business income. New York and London: Garland Publishing.

Edwards J. R. (2016). Asset valuation, profit measurement and path dependence in Britain to 1800. British accounting review, Vol. 48. № 1, pp. 87-101.

Gregory A., Whittaker J. (2013). Exploring the Valuation of Corporate Social ResponsibilityA Comparison of Research Methods. Journal of business ethics, Vol. 116, no. 1, pp. 1 -20.

Ivanov A. Y. (2014). A critical review of the main methods of goodwill valuation of nonpublic companies applied in planning of mergers and acquisitions. Financial Analytics: Science and Experience, no. 38, pp. 31-41. (Иванов А. Е. Критический обзор основных методов оценки гудвилла непубличных компаний, применяющих при планировании слияний и поглощений // Финансовая аналитика: проблемы решения. 2014. № 38 (224), c. 31-41). (in Russian) 
Koh P., Qian C., Wang H. (2014). Firm litigation risk and the insurance value of corporate social performance, Strategic management journal. Vol. 35, no. 10, pp.1464-1482.

Kuter M. I. (2013). Introduction to Accounting. - Krasnodar: Enlightenment SOUTH. - 512 p. (Кутер М. И. Введение в бухгалтерский учет. - Краснодар: Просвещение-ЮГ, 2013). (in Russian)

Peasnell K., Whittington G. (2010). The Contribution of Philip W. Bell to Accounting Thought. Accounting Horizons, vol. 24, no. 3, pp. 509-518.

Sokolov V. Y. (2006). The theoretical beginnings (basis) of double-entry bookkeeping - SPb: $\mathrm{SPbGUEF,} \mathrm{2006.} \mathrm{(Соколов} \mathrm{В.} \mathrm{Я.} \mathrm{Теоретические} \mathrm{начала} \mathrm{(основы)} \mathrm{двойной} \mathrm{бухгалтерии.} \mathrm{-}$ СПб.: Изд-во СПбГУЭФ, 2006). (in Russian)

Sokolov Y. V. (2010). Accounting as the sum of facts of economic life. Moscow, Magistr; INFRA-M. (Соколов Я. В. Бухгалтерский учет как сумма фактов хозяйственной жизни. - М.: Магистр; ИНФРА-М, 2010) (in Russian)

Sokolov Y. V. (2003). Basics of the accounting theory. Moscow, Finansy i statistika. (Соколов Я. В. Основы теории бухгалтерского учета. - М.: Финансы и статистика, 2003) (in Russian)

Sokolov V. Y. (1996). Estimations: their kinds and values. Accounting. 1996, no. 12, pp. 5559. (Соколов В. Я. Оценки: их виды и значение // Бухгалтерский учет. 1996. № 12, с. 55-59). (in Russian)

Sokolov Y. V. (1991). Sketches on accounting history. Moscow: Finansy i statistika. (Соколов Я. В. Очерки по истории бухгалтерского учета. - М.: Финансы и статистика, 1991) (in Russian)

Whittington G. (2015). 'Measurement in Financial Reporting: Half a Century of Research and Practice. Abacus, vol. 51, no. 4, pp. 549-71. 